\title{
Kajian Efek Ekstrak Umbi Bawang Dayak (Eleutherine palmifolia (L.) Merr) sebagai Antikanker
}

\author{
Roihatul Muti'ah* ${ }^{1}$, Anik Listiyana ${ }^{2}$ dan Belia Bima Nafisa ${ }^{1}$, Arief Suryadinata ${ }^{1}$ \\ ${ }^{1}$ Program Studi Farmasi, Universitas Islam Negeri Maulana Malik Ibrahim, Kota Batu, Indonesia \\ ${ }^{2}$ Program Studi Pendidikan Dokter, Universitas Islam Negeri Maulana Malik Ibrahim, Kota Batu, Indonesia \\ *E-mail: Roiha@farmasi.uin-malang.ac.id
}

\begin{abstract}
Dayak onion (Eleutherine palmifolia (L.) Merr) is a typical plant in Central Kalimantan. This plant has been passed down for generations by Indonesian people for various treatments. The potential of dayak onions that have various pharmacological activities needs to be increased in their use as modern medicinal ingredients. The purpose of this literature study is to review the various uses, the secondary metabolites content, and the action mechanism as an anticancer both in vitro, in vivo, and in silico. The results of this literature study show that traditionally the Indonesian people use the bulbs for the treatment of breast cancer, colon cancer, hypertension, diabetes mellitus, stroke, fever, dysuria, intestinal inflammation, dysentery, boils, cysts, prostate, lowering cholesterol and triglycerides, breastfeeding and sexual disorders. In the empiric treatment of cancer, this plant is used by drying the bulbs and chewing it. Dayak onion bulbs (Eleutherine palmifolia (L.) Merr) are known to contain flavonoid compounds wich isoliquiritigenin, polyphenols group wich oxyresveratrol and naphtoquinon group, and its derivatives such as elecanacine, eleutherine, eleutherol, eleutherinol, eleutherinon, eleuthoside $B$, eletherinoside $A$ which has anti-cancer activity. Pre-clinical studies with in vitro and in vivo mechanism showed that dayak onion bulbs (Eleutherine palmifolia (L.) Merr) extracts have pharmacological activities, which are anti-cancer that can inhibit cell signaling through apoptosis and cell cycle arrest. Also, the mechanism of in silico showed anti-cancer activity from the inhibition of VHR receptors, BCL-2 receptors, VEGFR-2 receptors and alpha estrogen receptors (ER $\alpha$ ).
\end{abstract}

Key words: Eleutherine palmifolia (L.) Merr, in vitro, in vivo, in silico, antikanker

\section{Pendahuluan}

Kanker adalah suatu penyakit yang tidak menular dengan ditandai adanya pertumbuhan sel yang tidak normal dan tidak terkendali yang dapat merusak jaringan sekitarnya. Sekitar sepuluh juta orang di seluruh dunia setiap tahunnya meninggal karena kanker. Pada tahun 2005 sampai tahun 2015 angka kematian karena kanker di seluruh dunia telah meningkat sekitar 17\% (Yang dkk., 2019). Berdasarkan data RISKESDES (Riset Kesehatan Dasar) tahun 2018, prevalensi kanker di Indonesia mencapai 1,79 per 1000 penduduk. Prevalensi kanker tertinggi yaitu di Daerah Istimewa Yogyakarta dengan 4,86 per 1000 penduduk, setelah itu Sumatera Barat 2,47 per 1000 penduduk, Gorontalo 2,44 per 1000 penduduk dan Daerah Khusus Ibu Kota Jakarta dengan 2,33 per 1000 penduduk (Kemenkes RI, 2018).
Terjadinya disregulasi siklus sel dan penurunan apoptosis sel menjadi salah satu penyebab sel kanker berkembang. Oleh karena itu, memerlukan adanya pengobatan untuk mencegah penyebaran sel kanker ke jaringan-jaringan yang ada di sekitarnya. Secara umum, terapi kanker secara medis dapat dilakukan melalui operasi, terapi hormonal, radioterapi atau kemoterapi (Sun dkk., 2017). Penggunaan metode terapi tersebut tergantung pada jenis tumor dan stadium perkembangannya. Adanya peningkatan prevalensi kanker pada setiap tahunnya, maka mendorong dilakukannya penelitian untuk menemukan agen antikanker dari produk alam sebagai upaya mencegah dan menyembuhkan kanker.

Indonesia dengan keanekaragaman hayatinya memiliki berbagai jenis tumbuhan yang memiliki banyak manfaat. Salah satu tumbuhan yang bisa diambil manfaatnya adalah bawang dayak. Bagian umbi dari bawang dayak (Eleutherine palmifolia (L.) Merr) dapat berkhasiat sebagai obat. Bawang dayak (Eleutherine palmifolia (L.) Merr) ini merupakan tanaman khas Kalimantan Tengah yang berasal dari Amerika 
tropis yang secara empiris umbinya berkhasiat untuk mengobati berbagai penyakit seperti luka, sakit kuning, batuk, sakit perut, disentri, diare berdarah, radang poros usus, kanker payudara, kanker colon, obat bisul dan perangsang muntah (Puspadewi dkk., 2013). Umbi bawang dayak (Eleutherine palmifolia (L.) Merr) mengandung senyawa metabolit sekunder golongan flavonoid (Hidayah dkk., 2015). Selain itu, umbi bawang dayak (Eleutherine palmifolia (L.) Merr) juga mengandung senyawa metabolit sekunder golongan naftokuinon dan turunannya seperti elecanacin, eleutherin, eleutherol, eleutherinol, eleutherinon, eleuthoside B dan eletherinoside A (Narko dkk., 2017). Menurut Muti'ah dkk (2019), umbi bawang dayak (Eleutherine palmifolia (L.) Merr) mengandung senyawa metabolit sekunder golongan polifenol, yaitu oxyresveratrol.

Studi pre klinik efek antikanker dari ekstrak etanol umbi bawang dayak (Eleutherine palmifolia (L.) Merr) telah banyak dilakukan, baik secara in vitro, in vivo maupun in silico. Diantaranya dapat menghambat proliferasi sel kanker payudara T47D, menghambat transkripsi TCF / $\beta$-catenin dalam sel kanker kolon SW480 dan menghambat pertumbuhan sel kanker serviks Hela. Selain itu, ekstrak etanol umbi bawang dayak (Eleutherine palmifolia (L.) Merr) juga memiliki aktivitas antikanker dari penghambatan reseptor VHR, BCL-2, VEGFR-2 dan reseptor estrogen alpha $(\mathrm{ER} \alpha)$. Hasil dari beberapa penelitian yang telah dilakukan dapat menjadi acuan bahwa ekstrak etanol umbi bawang dayak (Eleutherine palmifolia (L.) Merr) berpotensi sebagai agen antikanker. Sehingga, ekstrak etanol umbi bawang dayak (Eleutherine palmifolia (L.) Merr) layak untuk dilakukan penelitian lebih lanjut, karena belum adanya penelitian secara klinik penggunaan ekstrak etanol umbi bawang dayak (Eleutherine palmifolia (L.) Merr). Yang mana uji klinik dilakukan pada manusia untuk mempelajari efek farmakodinamik, farmakokinetik dan efek samping suatu obat.

Oleh karena itu, menarik untuk dikaji tentang efek ekstrak etanol umbi bawang dayak (Eleutherine palmifolia (L.) Merr) sebagai antikanker secara empiris dan efek ekstrak etanol umbi bawang dayak (Eleutherine palmifolia (L.) Merr) sebagai antikanker baik secara in vitro, in vivo maupun in silico untuk mengetahui mekanisme kerja dari kandungan senyawa kimia yang dimiliki umbi bawang dayak (Eleutherine palmifolia (L.) Merr). Sehingga dapat dijadikan acuan pembuktian ilmiah secara klinik dalam bentuk dosis yang bisa digunakan pada manusia.

\section{Bahan dan Metode}

\subsection{Jenis Penelitian}

Penelitian ini merupakan studi literatur yang mencari database dari berbagai referensi atau literatur, seperti jurnal penelitian ilmiah, review jurnal, skripsi dan buku.

\subsection{Metode Pencarian Keywords Literatur}

Pencarian literatur dilakukan dengan menggunakan keywords: Eleutherine palmifolia (L.) Merr, in vitro, in vivo, in silico, antikanker. Database internasional dapat diambil dari referensi atau literatur yang dipublikasikan pada PubMed, NCBI, PLoS, SciELO, Crossref, Library Genesis dan Google Scholar dengan menggunakan kata sambung and dan nor. Database dalam negeri dapat diambil dari referensi atau literatur yang dipublikasikan pada Depkes RI, Kemenkes RI dan Google Cendekia.

\subsection{Kriteria Inklusi dan Eksklusi Literatur}

Pencarian literatur juga dilakukan dengan skrining berdasarkan kriteria inklusi dan kriteria eksklusi, dimana kriteria tersebut menentukan dapat atau tidaknya literatur digunakan. Adapun kriteria inklusi literatur yaitu tanggal publikasi literatur pada tahun 2005 sampai 2020, bahasa publikasi literatur yaitu Bahasa Indonesia dan Bahasa Inggris, biografi tanaman berasal dari wilayah Indonesia, literatur yang merujuk sebagai agen antikanker, bahan yang digunakan yaitu ekstrak dan fraksi umbi bawang dayak, pelarut yang digunakan ekstraksi yaitu etanol dan pelarut yang digunakan fraksi yaitu kloroform dan etil asetat. Sedangkan kriteria eksklusi literatur yaitu tanggal publikasi literatur sebelum tahun 2005, bahasa publikasi literatur selain Bahasa Indonesia dan Bahasa Inggris, biografi tanaman berasal dari selain wilayah Indonesia, literatur yang merujuk selain sebagaiagen antikanker, bahan selain ekstrak dan fraksi umbi bawang dayak, pelarut yang digunakan ekstraksi selain etanol dan pelarut yang digunakan fraksi selain kloroform dan etil asetat.

\subsection{Analisis Data}

Analisis data dilakukan dengan cara menggabungkan sumber referensi yang terkait dan literatur yang memadai serta membantu dalam pengumpulan data dengan memberikan pemahaman dan penjelasan secukupnya. Hasilnya juga dapat disajikan dalam bentuk tabel.

\section{Hasil dan Pembahasan}

\subsection{Studi Empiris Umbi Bawang Dayak (Eleutherine palmifolia (L.) Merr) sebagai Antikanker}

Berbagai jenis tanaman obat memang sudah biasa digunakan sebagai obat dan dirasakan efektivitasnya secara empiris, salah satunya adalah bawang dayak (Eleutherine palmifolia (L.) Merr). Tanaman bawang dayak (Eleutherine palmifolia (L.) Merr) telah secara turun temurun digunakan masyarakat Indonesia khususnya suku Dayak sebagai tanaman obat. Menurut Wigati dan Ryan (2018), secara empiris bawang dayak (Eleutherine palmifolia (L.) Merr) digunakan untuk pengobatan kanker payudara, hipertensi, diabetes melitus, stroke dan penurun kolesterol serta trigliserida. Menurut Fitri dkk (2014), secara empiris bawang dayak (Eleutherine palmifolia (L.) Merr) digunakan sebagai obat tradisional untuk penyakit kanker usus besar. Menurut Lestari dkk (2019), secara empiris bawang dayak 
(Eleutherine palmifolia (L.) Merr) digunakan untuk mengobati penyakit jantung, penyakit tumor, sakit perut dan untuk meningkatkan daya tahan tubuh.

Menurut Hidayah dkk (2015), secara empiris bawang dayak (Eleutherine palmifolia (L.) Merr) dapat digunakan untuk mengurangi sakit perut setelah melahirkan. Menurut Prayitno dkk (2018), bagian umbi dari bawang dayak (Eleutherine palmifolia (L.) Merr) bermanfaat sebagai disuria, radang usus, disentri dan penyakit kuning. Menurut Pratama dan Isna (2019), secara empiris bawang dayak (Eleutherine palmifolia (L.) Merr) digunakan sebagai obat untuk demam akibat infeksi bakteri. Menurut Insanu dkk (2014), secara empiris bawang dayak (Eleutherine palmifolia (L.) Merr) digunakan untuk meningkatkan produksi ASI serta gangguan seksual. Menurut Ahmad dkk (2018), secara tradisional bawang dayak (Eleutherine palmifolia (L.) Merr) digunakan untuk pengobatan kista dan prostat.

Menurut Puspadewi dkk (2013), secara empiris umbi dari bawang dayak (Eleutherine palmifolia (L.) Merr) bersifat diuretik, astringen, pencahar dan analgetik. Selain itu, umbi bawang dayak (Eleutherine palmifolia (L.) Merr) juga dikenal memiliki khasiat untuk mengatasi bisul atau penyakit kulit. Cara penggunaannya yaitu dengan menempelkan parutan umbi bawang dayak (Eleutherine palmifolia (L.) Merr) pada daerah yang luka (Puspadewi dkk., 2013). Parutan umbi bawang dayak (Eleutherine palmifolia (L.) Merr) ditunjukkan pada gambar 1 .

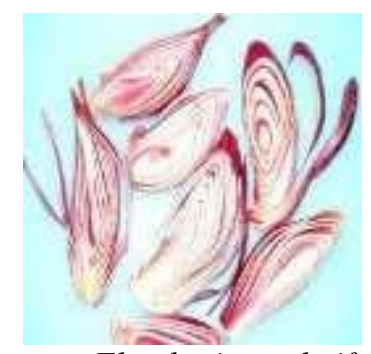

Gambar 1. Parutan Eleutherine palmifolia (L.) Merr

Suku Dayak memanfaatkan umbi bawang dayak (Eleutherine palmifolia (L.) Merr) untuk mengatasi berbagai penyakit dengan cara mengkonsumsi 3 kali sehari setiap hari, dengan 2 umbi sekali konsumsi. Selain itu, dapat juga dilakukan dengan mengambil 10 bagian umbi dari bawang dayak (Eleutherine palmifolia (L.) Merr), kemudian direbus dengan 3 gelas air hinga tersisa $1 \frac{1}{2}$ gelas dan diminum 3 kali sehari, yaitu $1 / 2$ gelas untuk sekali minum (Naspiah dkk., 2014). Air rebusan umbi bawang dayak (Eleutherine palmifolia (L.) Merr) ditunjukkan pada gambar 2.

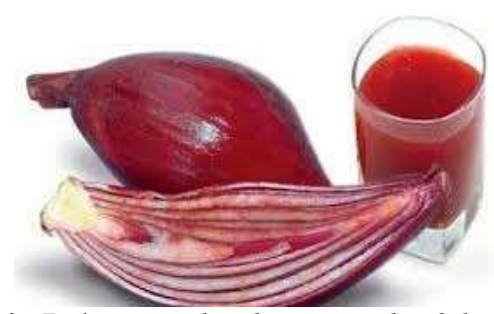

Gambar 2. Air Rebusan Eleutherine palmifolia (L.) Merr

Tanaman bawang dayak (Eleutherine palmifolia (L.)

Merr) juga digunakan sebagai fitoterapi dalam bentuk teh untuk mengobati diare yang disebabkan oleh amoeba (Entamoeba hystolitica / Entamoeba dispar) (Nascimento dkk., 2012). Selama ini masyarakat Kalimantan juga mempercayai bawang dayak (Eleutherine palmifolia (L.) Merr) sebagai obat tradisional yang memiliki potensi sebagai herba antikanker (Sudarmawan dkk, 2010). Secara empiris, umbi bawang dayak (Eleutherine palmifolia (L.) Merr) digunakan sebagai obat kanker dengan cara mengeringkan umbi dan mengunyahnya (Naspiah dkk., 2014). Umbi bawang dayak (Eleutherine palmifolia (L.) Merr) yang telah dikeringkan ditunjukkan pada gambar 3 .

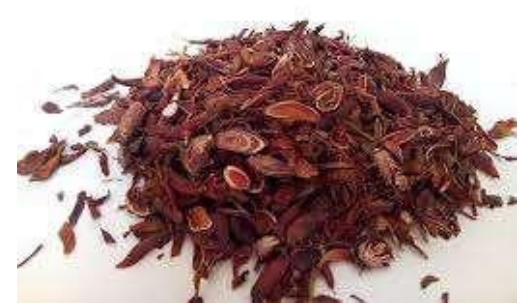

Gambar 3. Eleutherine palmifolia (L.) Merr Kering

\subsection{Kandungan Senyawa Aktif Ekstrak Eleutherine palmifolia (L.) Merr}

Kandungan senyawa aktif ekstrak umbi bawang dayak (Eleutherine palmifolia (L.) Merr) disajikan pada tabel di bawah ini:

Tabel 1 Kandungan senyawa aktif ekstrak Eleutherine palmifolia (L.) Merr

\begin{tabular}{|c|c|c|}
\hline Komponen Isolat & Mekanisme & Pustaka \\
\hline Eleutherol & $\begin{array}{l}\text { - Peningkatan aliran darah jantung } \\
\text { - Penghambatan replikasi HIV, } \mathrm{IC}_{50}=100 \mu \mathrm{g} / \mathrm{mL} \\
\text { - Aktif melawan jamur Aspergillus niger, Rhizopus sp. and } \\
\text { Penicillium sp. }\end{array}$ & $\begin{array}{l}\text { (Narko dkk, 2017; Hidayah } \\
\text { dkk., 2015; Prayitno dkk., } \\
\text { 2018; Chen dkk., 2018; } \\
\text { Mahabusarakam dkk., 2010; } \\
\text { Poerwosusanta dkk., } 2018 ; \\
\text { Insanu dkk., 2014). }\end{array}$ \\
\hline Eleutherin & $\begin{array}{l}\text { - Peningkatan aliran darah jantung } \\
\text { - Menghambat proliferasi K562 (sel leukimia), } \mathrm{IC}_{50}=49 \mu \mathrm{g} / \mathrm{mL} \\
\text { - Menghambat topoisomerase II manusia dengan } \mathrm{IC}_{50}=50 \\
\mu \mathrm{g} / \mathrm{mL}\end{array}$ & $\begin{array}{l}\text { (Narko dkk., 2017; Hidayah } \\
\text { dkk., 2015; Prayitno dkk., } \\
\text { 2018; Mahabusarakam dkk., } \\
\text { 2010; Poerwosusanta dkk., }\end{array}$ \\
\hline
\end{tabular}




\begin{tabular}{|c|c|}
\hline & $\begin{array}{l}\text { - Menghambat transkripsi TCF / } \beta \text {-catenin dalam sel kanker } \\
\text { kolon SW480 } \\
\text { - Aktif melawan jamur Aspergillus niger, Rhizopus sp. and } \\
\text { Penicillium sp } \\
\text { - Menghambat produksi NO sebagai zat pemicu inflamasi dalam } \\
\text { sel makrofag } \\
\text { - Menghambat pembentukan melanin, sebagai antidermatofit dan } \\
\text { antimelanogenesis }\end{array}$ \\
\hline Isoeleuterin & $\begin{array}{l}\text { - Peningkatan aliran darah jantung } \\
\text { - Menghambat proliferasi K562 (sel leukimia), } \mathrm{IC}_{50}=33 \mu \mathrm{g} / \mathrm{mL} \\
\text { - Menghambat replikasi HIV pada Hg lymphocytes, } \mathrm{IC}_{50}=8.5 \\
\mu \mathrm{g} / \mathrm{mL} \\
\text { - Menghambat NFאB sel makrofag } \\
\text { - Menekan ekspresi inducible Nitric Oxide Syntase (iNOS) } \\
\text { (mediator inflamasi) pada sel makrofag. } \\
\text { - Aktif melawan jamur Aspergillus niger, Rhizopus } \text { sp. and } \\
\text { Penicillium sp. }\end{array}$ \\
\hline
\end{tabular}

2018; Li dkk., 2009; Insanu dkk., 2014).

(Nascimento dkk, 2012; Narko dkk, 2017; Prayitno dkk., 2018; Mahabusarakam dkk., 2010; Poerwosusanta dkk., 2018; Insanu dkk., 2014).

\begin{tabular}{llc}
\hline $\begin{array}{l}\text { 4,8-dihidroksi-3- } \\
\text { methoxy-1-metil } \\
\text { antrakuinon-2- asam } \\
\text { karbosilat metil ester }\end{array}$ & Belum ada laporannya & (Prayitno dkk., \\
& & Mahabusarakam dkk., 2010) \\
& & \\
\hline $\begin{array}{l}\text { 8-hidroksi-3,4- } \\
\text { dimetoksi-1- }\end{array}$ & - Menghambat proliferasi K562 (sel leukimia), IC $50=266 \mu \mathrm{g} / \mathrm{mL}$ & (Prayitno dkk., 2018; \\
metilantra kuinon-2- & Mahabusarakam dkk., 2010; \\
asam karboksilat & Poerwosusanta dkk., 2018). \\
metil ester & &
\end{tabular}

\begin{tabular}{|c|c|c|}
\hline $\begin{array}{l}\text { 3,4,8-trimetoksi-1- } \\
\text { metilantra quinone- } \\
\text { 2- asam karboksilat } \\
\text { metil ester }\end{array}$ & Belum ada laporannya & (Prayitno dkk., 2018) \\
\hline Hongconin & $\begin{array}{l}\text { - Menghambat proliferasi K562 (sel leukimia), } \mathrm{IC}_{50}=174 \mu \mathrm{g} / \mathrm{mL} \\
\text { - Aktif melawan jamur Aspergillus niger, Rhizopus sp. and } \\
\text { Penicillium sp } \\
\text { - } \text { Menghambat produksi NO sebagai zat pemicu inflamasi dalam } \\
\text { sel makrofag }\end{array}$ & $\begin{array}{l}\text { (Prayitno dkk., 2018; Chen } \\
\text { dkk., 2018; Hara dkk., 1997; } \\
\text { Mahabusarakam dkk., 2010; } \\
\text { Poerwosusanta dkk., 2018; } \\
\text { Insanu dkk., 2014). }\end{array}$ \\
\hline Elecanacin & $\begin{array}{l}\text { - Menghambat transkripsi TCF / } \beta \text {-catenin dalam sel kanker } \\
\text { kolon SW480 } \\
\text { - Peningkatan c-myc untuk apoptosis sel kanker } \\
\text { - Aktif melawan jamur Aspergillus niger, Rhizopus sp. and } \\
\text { Penicillium sp }\end{array}$ & $\begin{array}{l}\text { (Narko dkk, 2017; Hidayah } \\
\text { dkk., 2015; Prayitno dkk., } \\
\text { 2018; Mahabusarakam dkk., } \\
\text { 2010; Li dkk., 2009; Insanu } \\
\text { dkk., 2014). }\end{array}$ \\
\hline Isoeleutherol & - Menghambat replikasi HIV $\mathrm{IC}_{50}=100 \mu \mathrm{g} / \mathrm{mL}$ & $\begin{array}{l}\text { (Prayitno dkk., } 2018 ; \\
\text { Poerwosusanta dkk., 2018). }\end{array}$ \\
\hline $\begin{array}{l}\text { (-)-3-[2- } \\
\text { (asetiloksi)propil]-2- } \\
\text { hidroksi-8-metoksi- } \\
\text { 1,4-naftakuinon }\end{array}$ & Belum ada laporannya & $\begin{array}{l}\text { (Prayitno dkk., 2018; } \\
\text { Mahabusarakam dkk., 2010) }\end{array}$ \\
\hline Eleuterinol & $\begin{array}{l}\text { - Menghambat produksi NO sebagai zat pemicu inflamasi dalam } \\
\text { sel makrofag }\end{array}$ & $\begin{array}{l}\text { (Prayitno dkk., 2018; Naspiah } \\
\text { dkk., 2014). }\end{array}$ \\
\hline
\end{tabular}

\begin{tabular}{lll}
\hline 1,5-dihidroksi-3- & Belum ada laporannya & (Prayitno dkk., 2018) \\
methilantrakuinon &
\end{tabular}




\begin{tabular}{|c|c|c|}
\hline Dihydroeleuterinol & $\begin{array}{l}\text { - Menghambat proliferasi sel K562 (sel eritroleukimia manusia) } \\
\text { dengan nilai IC50 = } 154 \mu \mathrm{mol} / \mathrm{L} \\
\text { - Menghambat produksi NO sebagai zat pemicu inflamasi dalam } \\
\text { sel makrofag }\end{array}$ & (Prayitno dkk., 2018) \\
\hline Dihydroisoeleutherin & Belum ada laporannya & (Chen dkk., 2018) \\
\hline & Belum ada laporannya & (Prayitno dkk., 2018) \\
\hline \multicolumn{3}{|l|}{$\begin{array}{l}\text { 2,5-dimetil-10- } \\
\text { hidroksinaftopiron } 8 \text { - } \\
\text { O- } \beta \text {-glukopiranosida }\end{array}$} \\
\hline Eleutosida A & Belum ada laporannya & (Prayitno dkk., 2018) \\
\hline Eleuthosida B & Belum ada laporannya & $\begin{array}{l}\text { (Narko dkk, 2017; Prayitno } \\
\text { dkk., 2018) }\end{array}$ \\
\hline Eleuthosida C & Belum ada laporannya & (Narko dkk, 2017) \\
\hline Eleuthinone A & Belum ada laporannya & $\begin{array}{l}\text { (Prayitno dkk., } \\
\text { Mahabusarakam dkk., 2010) }\end{array}$ \\
\hline Eleuthinone B & Belum ada laporannya & (Chen dkk., 2018) \\
\hline Eleuthinone $\mathrm{C}$ & Belum ada laporannya & (Chen dkk., 2018) \\
\hline Eleutraquinon $\mathrm{A}$ & Belum ada laporannya & $\begin{array}{l}\text { (Prayitno dkk., } 2018 ; \\
\text { Mahabusarakam dkk., 2010) }\end{array}$ \\
\hline Eleutraquinon B & Belum ada laporannya & $\begin{array}{l}\text { (Prayitno dkk., } 2018 ; \\
\text { Mahabusarakam dkk., 2010) }\end{array}$ \\
\hline Eleucanarol & Belum ada laporannya & $\begin{array}{l}\text { Prayitno dkk., } 2018 ; \\
\text { Mahabusarakam dkk., 2010) }\end{array}$ \\
\hline $\begin{array}{l}\text { 1,2-dihidroksi-8- } \\
\text { metoksi-3- } \\
\text { metilantrakuinon }\end{array}$ & Belum ada laporannya & $\begin{array}{l}\text { (Prayitno dkk., } 2018 ; \\
\text { Mahabusarakam dkk., 2010) }\end{array}$ \\
\hline
\end{tabular}

\begin{tabular}{|c|c|c|}
\hline Eleuterinosida A & $\begin{array}{l}\text { - Inhibitor } \alpha \text {-glucosidase, } \mathrm{IC}_{50}=0,5 \mathrm{mM} \text { (antidiabetes) } \\
\text { - Menghambat pertumbuhan kanker serviks dengan nilai ikatan } \\
\text { energi sebesar }-9,55 \mathrm{kkal} / \mathrm{mol} \text { terhadap reseptor 5UU1 (secara } \\
\text { in silico) } \\
\text { - Menghambat pertumbuhan kanker serviks dengan nilai ikatan } \\
\text { energi sebesar -7,63 kkal/mol terhadap reseptor 3ERT (secara } \\
\text { in silico) }\end{array}$ & $\begin{array}{l}\text { (Narko dkk, 2017; Prayitno } \\
\text { dkk., 2018; Poerwosusanta } \\
\text { dkk., 2018; Insanu dkk., 2014; } \\
\text { Ha dkk., 2013). }\end{array}$ \\
\hline Eleuterinosida B & Belum ada laporannya & $\begin{array}{l}\text { (Narko dkk, 2017; Prayitno } \\
\text { dkk., 2018;) }\end{array}$ \\
\hline $\begin{array}{l}\text { 1,3,6-trihidroksi-8- } \\
\text { metilantrakuinon }\end{array}$ & - Menghambat proliferasi K562 (sel leukimia), $\mathrm{IC}_{50}=154 \mu \mathrm{g} / \mathrm{mL}$ & $\begin{array}{l}\text { (Prayitno dkk., } 2018 ; \\
\text { Mahabusarakam dkk., 2010; } \\
\text { Poerwosusanta dkk., 2018). }\end{array}$ \\
\hline$\beta$-sitosterol & Belum ada laporannya & (Prayitno dkk., 2018) \\
\hline Asam kadsurat & Belum ada laporannya & (Prayitno dkk., 2018) \\
\hline $\begin{array}{l}\text { 9,9A-dihidroksi- } \\
\text { 8,8'-dimetoksi-1'- } \\
\text { dimethyl- } 1 \mathrm{H}, 1 \mathrm{H} \text { '- } \\
\text { [4,4']bis[nafta[2,3- } \\
\text { c]funanil]3,3'-dion }\end{array}$ & Belum ada laporannya & (Prayitno dkk., 2018) \\
\hline
\end{tabular}




\begin{tabular}{|c|c|c|}
\hline $\begin{array}{l}\text { 6,8-dihidroksi-3,4- } \\
\text { dimetoksi-1-metil- } \\
\text { antraquin-on-2-asam } \\
\text { karboksilat metal } \\
\text { ester }\end{array}$ & $\begin{array}{l}\text { - Menghambat proliferasi K562 (sel leukimia) dengan } \mathrm{IC}_{50}=49.1 \\
\mu \mathrm{g} / \mathrm{mL}\end{array}$ & $\begin{array}{l}\text { (Prayitno dkk., } 2018 ; \\
\text { Poerwosusanta dkk., 2018). }\end{array}$ \\
\hline $\begin{array}{l}\text { 2-asetill-3,6,8- } \\
\text { trihidroksi-1- } \\
\text { metilantrakuinon }\end{array}$ & Belum ada laporannya & $\begin{array}{l}\text { (Prayitno dkk., 2018; } \\
\text { Mahabusarakam dkk., 2010) }\end{array}$ \\
\hline 4-hidroksi-eleuterin & $\begin{array}{l}\text { - Menghambat proliferasi K562 (sel leukimia) dengan } \mathrm{IC}_{50}=35 \\
\mu \mathrm{g} / \mathrm{mL}\end{array}$ & $\begin{array}{l}\text { (Prayitno dkk., 2018; } \\
\text { Poerwosusanta dkk., 2018). }\end{array}$ \\
\hline
\end{tabular}

\section{2,5-dimetil-10-}

Belum ada laporannya

(Prayitno dkk., 2018)

hidroksinaftopiron 8-

O- $\beta$-glukopiranosida

\begin{tabular}{|c|c|c|}
\hline Eleutosida $\mathrm{C}$ & Belum ada laporannya & (Prayitno dkk., 2018) \\
\hline $\begin{array}{l}\text { 9,10-dihidro-8- } \\
\text { hidroksi-3,4- } \\
\text { dimetoksi-9,10- } \\
\text { diokso-2-antrasene } \\
\text { asam karboksilat } \\
\text { metil ester }\end{array}$ & Belum ada laporannya & (Prayitno dkk., 2018) \\
\hline Erythrolaccin & Belum ada laporannya & $\begin{array}{l}\text { (Narko dkk, 2017; Prayitno } \\
\text { dkk., 2018; Mahabusarakam } \\
\text { dkk., 2010) }\end{array}$ \\
\hline Eleutherinone & Belum ada laporannya & $\begin{array}{l}\text { (Narko dkk, 2017; Hidayah } \\
\text { dkk., 2015) }\end{array}$ \\
\hline Eleutherinol & $\begin{array}{l}\text { - Menghambat reseptor estrogen alpha }(\mathrm{ER} \alpha) \text { kanker payudara } \\
\text { dengan nilai ikatan energi sebesar }-6,43 \mathrm{kkal} / \mathrm{mol} \text { terhadap } \\
\text { reseptor 3ERT (secara in silico) }\end{array}$ & $\begin{array}{l}\text { (Narko dkk, 2017; Ha dkk., } \\
\text { 2013) }\end{array}$ \\
\hline Isoliquiritigenin & $\begin{array}{l}\text { - Meningkatkan aktivitas apoptosis sel kanker kolon melalui } \\
\text { ekspresi caspase-3 dan TNF- } \alpha \\
\text { - Menghambat ekspresi enzim topoisomerase I dan } \\
\text { topoisomerase II yang berperan dalam katalisis pemutaran dan } \\
\text { relaksasi DNA } \\
\text { - Menekan proliferasi sel kanker serviks dengan penghambatan } \\
\text { jalur estrogen alpha / Er- } \alpha \\
\text { - Menghambat sel kanker metastasis melalui penghambatan } \\
\text { neoangiogenesis dalam VEGF / VEGFR-2 Signaling Pathway } \\
\text { - Menghambat proliferasi sel kanker pada fase G2/M dengan } \\
\text { menurunkan cyclin B, cell-division cycle } 2 \text { (cdc } 2 \text { ), dan cdc } 25 \mathrm{c}\end{array}$ & $\begin{array}{l}\text { (Minggarwati, 2017; Muti'ah } \\
\text { dkk., 2019; Wang dkk., 2013). }\end{array}$ \\
\hline Oxyresveratrol & $\begin{array}{l}\text { - Meningkatkan jumlah sel goblet yang memroduksi mucin } \\
\text { terutama MUC2. } \\
\text { - Meningkatkan NAD+ dengan menstimulasi enzim yang } \\
\text { berperan dalam biosinteis NAD+ untuk penurunan stress } \\
\text { oksidatif } \\
\text { - Meningkatkan integritas tight junction yang berfungsi dalam } \\
\text { diferensiasi sel dan memperbaiki struktur kripta pada kolon. }\end{array}$ & $\begin{array}{l}\text { (Minggarwati, 2017; Muti’ah } \\
\text { dkk., 2019) }\end{array}$ \\
\hline
\end{tabular}

\subsection{Studi Ilmiah tentang Antikanker dan Mekanisme Kerja}

Beberapa penelitian ilmiah yang sudah dilakukan lebih bersifat pembuktian atas rasionalitas atau irrasionalitas penggunaan jenis tanaman sebagai obat dan bukan suatu pencarian obat baru. Dari studi empiris yang telah diperoleh mengenai umbi bawang dayak (Eleutherine palmifolia (L.) Merr) yang dapat digunakan sebagai obat kanker, maka perlu juga dilakukan pengkajian ilmiah baik secara in vitro, in vivo, maupun in silico untuk mengetahui aktivitas farmakologi 
sebagai upaya untuk pembuktian tingkat efek sitotoksitas umbi bawang dayak (Eleutherine palmifolia (L.) Merr).

Umbi bawang dayak (Eleutherine palmifolia (L.) Merr) mengandung senyawa metabolit sekunder golongan flavonoid. Flavonoid merupakan senyawa yang terbukti dapat menyebabkan apoptosis sel dan menghambat proliferasi beberapa sel kanker (Mardiyaningsih dan Ismiyati, 2014). Mekanisme kerja flavonoid dalam apoptosis sel ditunjukkan pada gambar 4.

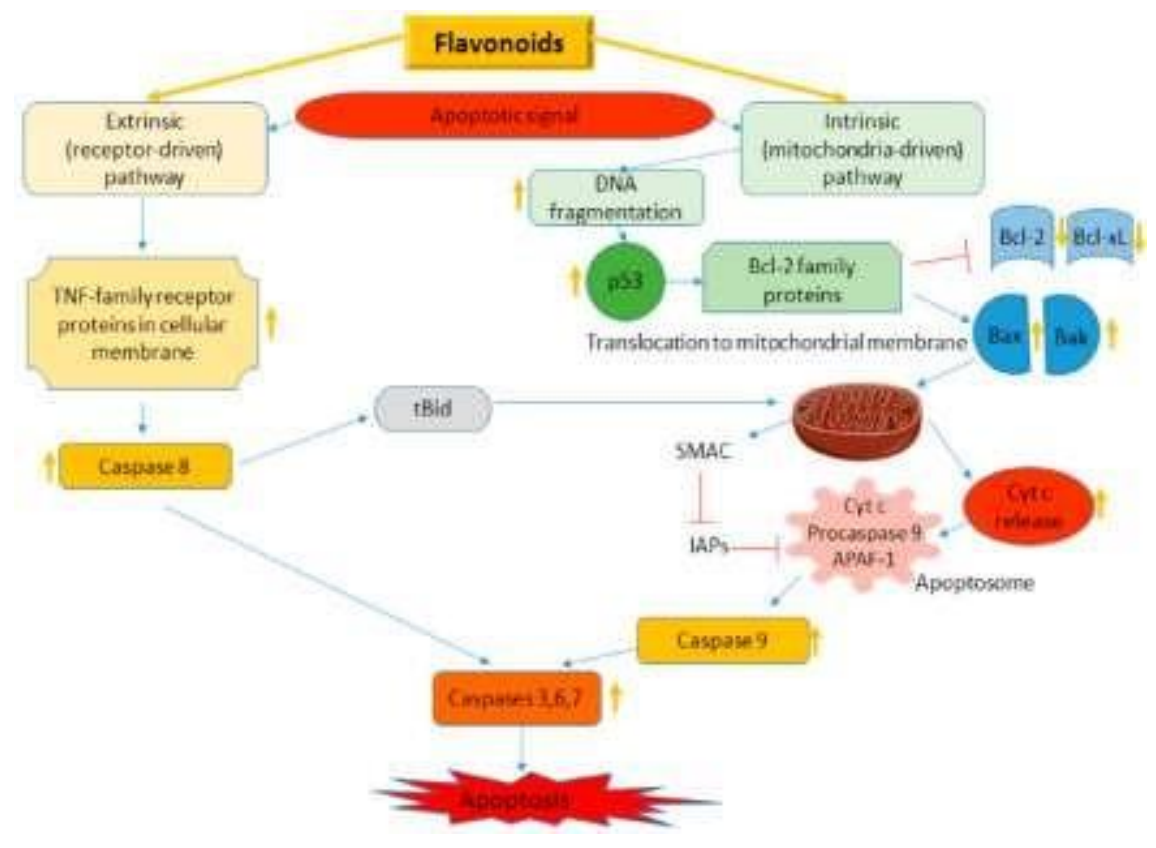

Gambar 4. Mekanisme Kerja Flavonoid dalam Apoptosis Sel (Kopustinskiene dkk., 2020 )

Telah banyak dibuktikan bahwa flavonoid memiliki aktivitas sebagai antikanker. Stres oksidatif, hipoksia, mutasi genetik dan kurangnya fungsi apoptosis adalah penyebab utama kanker, sedangkan penyebab eksternal terkait dengan peningkatan paparan stres, polusi, merokok, radiasi dan sinar ultraviolet. Metabolisme yang berubah, gangguan siklus sel, mutasi yang sering, resistensi terhadap respon imun, peradangan kronis, pembentukan metastasis, dan induksi angiogenesis adalah karakteristik utama sel kanker. Sel-sel kanker resisten terhadap kematian sel yang terprogram (apoptosis), biasanya diinduksi oleh serangkaian jalur transduksi sinyal serta protein pro-apoptosis caspases dan protein family Bcl-2. Ada dua jalur pensinyalan utama apoptosis, yang pertama jalur ekstrinsik, terkait dengan family reseptor nekrosis tumor (TNF) dengan protein pensinyalan utama caspase 8 . Yang kedua yaitu jalur intrinsik terkait jalur mitokondria, di mana protein keluarga Bcl-2 meluncurkan aktivasi caspases 9,3 dan 7. Ada ekspresi gen onkogenik yang berlebihan (misalnya, c-Myc), menyebabkan proliferasi sel dan penekanan $\mathrm{p} 53$, dan mengaktifkan protein anti-apoptosis dari keluarga Bcl-2 dalam sel kanker, sedangkan protein pro-apoptosis dan caspases dapat diturunkan regulasi. Flavonoid dapat menargetkan jalur pensinyalan apoptosis yang merangsang jalur kematian sel (Kopustinskiene dkk., 2020 ).

Flavonoid yang bertindak sebagai pro-oksidan dapat menekan proliferasi sel kanker dengan menghambat epidermal faktor pertumbuhan reseptor / pengaktifan mitogen protein kinase (EGFR / MAPK), phosphatidylinositide 3kinases (PI3K), protein kinase B (Akt) serta faktor nuklir kappa-lightchain-enhancer sel B teraktivasi (NF- $\kappa \mathrm{B})$. Dengan demikian, flavonoid dapat mengaktifkan jalur pensinyalan kematian sel terprogram dalam sel kanker dengan mekanisme ganda yaitu mengaktifkan protein anti-apoptosis serta menekan protein dan caspases pro-apoptosis. 


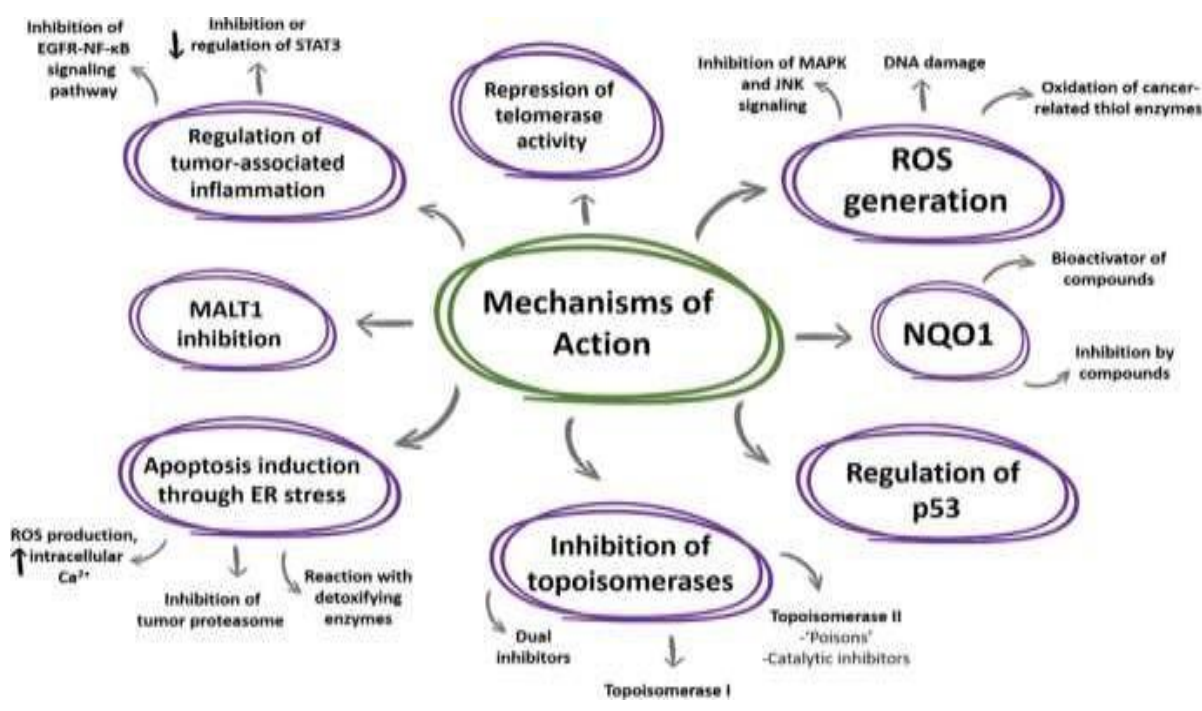

Gambar 5. Mekanisme Kerja Naftokuinon sebagai Antikanker (Pereyra dkk., 2019)

Selain itu, umbi bawang dayak (Eleutherine palmifolia (L.) Merr) mengandung senyawa metabolit sekunder golongan naftokuinon. Mekanisme kerja naftokuinon sebagai antikanker ditunjukkan pada gambar 5. Menurut Pereyra dkk (2019), Naftokuinon dapat membunuh atau menginduksi kematian sel dengan lebih dari satu mekanisme. Sitotoksisitas telah dikaitkan dengan penghambatan topoisomerase DNA manusia I dan II, kerusakan DNA (generasi ROS dan stres oksidatif), pengaktifan p53 sebagai respons terhadap kerusakan DNA, regulasi peradangan terkait tumor,penghambatan MALT1, induksi apoptosis melalui penekanan ER, represi aktivitas telomerase dan penekanan NQO1.

\section{A. Studi Pre Klinik dan Mekanisme Kerja secara In Vitro} Aktivitas antikanker umbi bawang dayak (Eleutherine palmifolia (L.) Merr) dapat dievaluasi dengan mengetahui efek sitotoksisitasnya suatu senyawa secara in vitro pada berbagai macam sel kanker. Menurut Zuhud (2011), senyawa sitotoksik adalah senyawa yang dapat bersifat toksik untuk menghambat dan menghentikan pertumbuhan sel kanker. Hasil penelitian Putri dan Haryoto (2018), menunjukkan bahwa ekstrak etanol umbi bawang dayak memiliki aktivitas sitotoksik terhadap sel T47D kanker payudara dengan nilai $\mathrm{IC}_{50} 255,363 \mu \mathrm{g} / \mathrm{mL}$. Senyawa golongan flavonoid mampu menghambat proliferasi melalui inhibisi proses oksidatif yang dapat menyebabkan inisiasi kanker dan menghambat ekspresi enzim topoisomerase I dan topoisomerase II yang berperan dalam katalisis pemutaran dan relaksasi DNA. Penelitian lain menurut Sudarmawan dkk (2010), membuktikan bahwa pemberian ekstrak etanol umbi bawang dayak mampu menekan tingkat ekspresi gen p53 mutan pada galur sel T47D kanker payudara secara in vitro dengan $\mathrm{LC}_{50}=125 \mu \mathrm{g} / \mathrm{mL}$. Senyawa flavonoid mampu mengurangi aktivasi oncogene, memacu terjadinya apoptosis, dan berpotensi untuk mengaktivasi proses DNA repair.
Penelitian menurut Li dkk (2009), membuktikan bahwa senyawa golongan naftokuinon dalam ekstrak etanol umbi bawang dayak juga diketahui menghambat transkripsi TCF / $\beta$-catenin dalam sel SW480 kanker kolon. Senyawa golongan naftokuinon berfungsi untuk membentuk tipe kompleks dengan topoisomerase II dengan stereospesifik dan penghambatan aktivitas selektif. Selain itu, senyawa golongan naftokuinon berperan dalam peningkatan c-myc untuk apoptosis.Hasil penelitian Yusni (2008), juga membuktikan bahwa ekstrak etanol umbi bawang dayak mempunyai efek sitotoksik terhadap sel karsinoma kolon HT29 dengan nilai $\mathrm{LC}_{50}$ sebesar 3,125 $\mu \mathrm{l} / \mathrm{mL}$. Efek sitostoksik tersebut disebabkan oleh aktivias senyawa flavonoid yang menyebabkan adanya penekanan ekspresi dari p53 mutan yang memacu proses apoptosis.

Penelitian Muti'ah dkk (2018), membuktikan bahwa ekstrak etanol umbi bawang dayak mampu menghambat pertumbuhan sel kanker serviks Hela melalui penghambatan siklus pertumbuhan sel dan induksi apoptosis sel dengan $\mathrm{IC}_{50}$ $40,36 \mu \mathrm{g} / \mathrm{mL}$. Senyawa golongan flavonoid yang mampu menghambat pertumbuhan kanker melalui penghambatan siklus pertumbuhan sel dan induksi apoptosis sel. Penghambatan sel kanker serviks terjadi di jalur estrogen / Er$\alpha$ sehingga dapat menekan proliferasi sel pada kanker serviks Senyawa ini telah terbukti mampu menghambat sel kanker metastasis melalui penghambatan neoangiogenesis dalam VEGF / VEGFR-2 Signaling Pathway. Flavonoid juga memiliki kemampuan menghambat proliferasi sel kanker pada fase $\mathrm{G} 2 / \mathrm{M}$ dengan menurunkan cyclin $\mathrm{B}$, cell-division cycle 2 (cdc 2), dan cdc 25c. Penelitian lain menurut Muti'ah dkk (2019), fraksi etil asetat dari ekstak etanol $96 \%$ umbi bawang dayak memiliki sitotoksisitas terhadap sel kanker serviks HeLa dengan $\mathrm{IC}_{50} 44,34 \mu \mathrm{g} / \mathrm{mL}$. Senyawa isoliquiritigenin dan oxyresveratrol memiliki aktivitas antiproliferatif dengan penurunan viabilitas sel, menginduksi akumulasi sel dalam fase G2 / M dan fitur morfologis serta biokimia dari apoptosis 
dan juga menghambat aktivitas NF- $\mathrm{BB}$ terhadap sel kanker serviks HeLa. Beberapa studi pre-klinik dengan mekanisme kerja secara in vitro dirangkum pada tabel 2.

Tabel 2. Rangkuman studi pre-klinik dan mekanisme kerja secara in vitro

\begin{tabular}{|c|c|c|c|c|c|}
\hline No. & Bahan & $\begin{array}{l}\text { Senyawa/ } \\
\text { Golongan } \\
\text { Senyawa }\end{array}$ & Aktivitas & Mekanisme Kerja & Pustaka \\
\hline 1. & $\begin{array}{l}\text { Ekstrak } \\
\text { Etanol } 96 \% \\
\text { umbi bawang } \\
\text { dayak } \\
\text { (Eleutherine } \\
\text { palmifolia (L.) } \\
\text { Merr) }\end{array}$ & $\begin{array}{l}\text { Golongan } \\
\text { flavonoid }\end{array}$ & $\begin{array}{l}\text { Aktivitas sitotoksik } \\
\text { terhadap sel T47D } \\
\text { kanker payudara } \\
\text { dengan nilai } \mathrm{IC}_{50} \\
255,363 \mu \mathrm{g} / \mathrm{mL} \text {. }\end{array}$ & 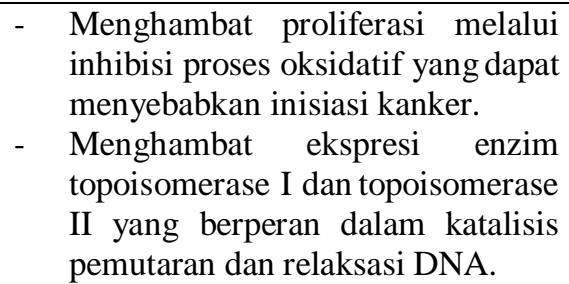 & $\begin{array}{l}\text { Putri } \\
\text { Haryoto } \\
(2018)\end{array}$ \\
\hline 2. & $\begin{array}{l}\text { Ekstrak } \\
\text { etanol } 96 \% \\
\text { umbi bawang } \\
\text { dayak } \\
\text { (Eleutherine } \\
\text { palmifolia (L.) } \\
\text { Merr) }\end{array}$ & $\begin{array}{l}\text { Golongan } \\
\text { flavonoid }\end{array}$ & $\begin{array}{l}\text { Aktivitas sitotoksik } \\
\text { terhadap sel T47D } \\
\text { kanker payudara } \\
\text { dengan nilai } \mathrm{LC}_{50} \\
125 \mu \mathrm{g} / \mathrm{mL}\end{array}$ & 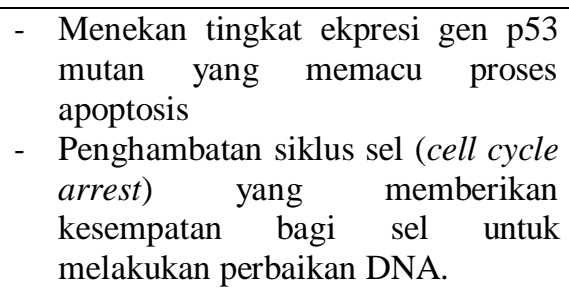 & $\begin{array}{l}\text { Sudarmawan } \\
\text { dkk (2010) }\end{array}$ \\
\hline 3. & $\begin{array}{l}\text { Ekstrak } \\
\text { Etanol umbi } \\
\text { bawang dayak } \\
\text { (Eleutherine } \\
\text { palmifolia }(\mathrm{L} .) \\
\text { Merr) }\end{array}$ & $\begin{array}{l}\text { Golongan } \\
\text { naftokuinon }\end{array}$ & $\begin{array}{lr}\text { Aktivitas sitotoksik } \\
\text { terhadap } r \text { sel } \\
\text { SW480 } \\
\text { kolon }\end{array}$ & $\begin{array}{l}\text { - Menghambat transkripsi TCF / } \beta \text { - } \\
\text { catenin dalam sel kanker } \\
\text { - Membentuk tipe kompleks dengan } \\
\text { topoisomerase II dengan } \\
\text { stereospesifik dan penghambatan } \\
\text { selektif aktivitas } \\
\text { - Meningkatkan c-myc untuk } \\
\text { apoptosis }\end{array}$ & Li dkk (2009) \\
\hline 4. & $\begin{array}{l}\text { Ekstrak } \\
\text { etanol } 96 \% \\
\text { umbi bawang } \\
\text { dayak } \\
\text { (Eleutherine } \\
\text { palmifolia (L.) } \\
\text { Merr) }\end{array}$ & $\begin{array}{l}\text { Golongan } \\
\text { flavonoid }\end{array}$ & $\begin{array}{l}\text { Aktivitas sitotoksik } \\
\text { terhadap sel } \\
\text { karsinoma kolon } \\
\text { HT29 dengan nilai } \\
\text { LC }_{50} \text { sebesar } 3,125 \\
\mu 1 / \mathrm{mL}\end{array}$ & $\begin{array}{l}\text { - Menghambat pertumbuhan sel } \\
\text { kanker dan Menekan tingkat } \\
\text { ekspresi p53 mutan } \\
\text { - Memacu proses apoptosis }\end{array}$ & Yusni (2008) \\
\hline 5. & $\begin{array}{l}\text { Ekstrak } \\
\text { etanol } 96 \% \\
\text { umbi bawang } \\
\text { dayak } \\
\text { (Eleutherine } \\
\text { palmifolia (L.) } \\
\text { Merr) }\end{array}$ & $\begin{array}{l}\text { Golongan } \\
\text { flavonoid }\end{array}$ & 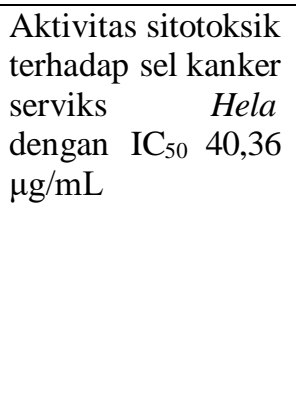 & $\begin{array}{l}\text { - Menghambat di jalur estrogen / Er- } \alpha \\
\text { yang dapat menekan proliferasi sel } \\
\text { - Menghambat sel kanker metastasis } \\
\text { melalui penghambatan } \\
\text { neoangiogenesis dalam VEGF / } \\
\text { VEGFR-2 Signaling Pathway } \\
\text { - Menghambat proliferasi sel pada fase } \\
\text { G2/M dengan menurunkan cyclin B, } \\
\text { cell-division cycle } 2 \text { (cdc 2), dan cdc } \\
\text { 25c }\end{array}$ & $\begin{array}{l}\text { Muti'ah } \\
\text { (2018) }\end{array}$ \\
\hline 6. & $\begin{array}{l}\text { Fraksi etil asetat } \\
\text { umbi bawang } \\
\text { dayak } \\
\text { (Eleutherine } \\
\text { palmifolia }(\mathrm{L} .) \\
\text { Merr) }\end{array}$ & $\begin{array}{l}\text { - Isoliquiritige } \\
\text { nin } \\
\text { - oxyresveratr } \\
\text { ol }\end{array}$ & 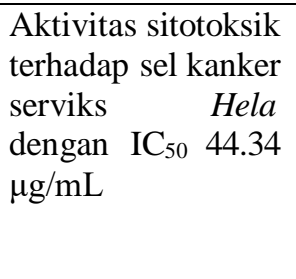 & 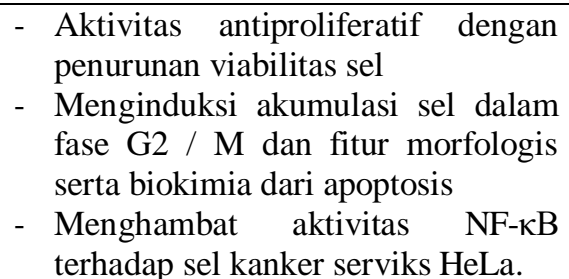 & $\begin{array}{l}\text { Muti'ah dkk } \\
\text { (2019) }\end{array}$ \\
\hline
\end{tabular}




\section{B. Studi Pre Klinik dan Mekanisme Kerja secara In Vivo} Penelitian lain yang dilakukan secara in vivo juga menemukan bahwa adanya efek antikanker dari umbi bawang dayak. Hasil penelitian Sari (2019), menunjukkan bahwa pemberian ekstrak etanol umbi bawang dayak dengan dosis $0,50 \mathrm{mg} / 20 \mathrm{gBB}$ dapat meningkatkan panjang kripta dan jumlah sel goblet secara signifikan serta dapat menurunkan skor histopatologi hepar pada kanker kolon. Senyawa oxyresveratrol (polifenol) dan isoliquiritigenin (flavonoid) yang terkandung dalam ekstrak etanol umbi bawang dayak diduga berperan sebagai antikanker kolon. Senyawa oxyresveratrol dilaporkan dapat meningkatkan jumlah sel goblet yang memproduksi mucin terutama MUC2. Mekanisme senyawa oxyresveratrol ini dihubungkan dengan peningkatan sintesis NAD+ yang berfungsi untuk menurunkan stress oksidatif. Selain itu, senyawa oxyresveratrol juga meningkatkan integritas tight junction dengan mengaktivasi fosforilasi protein kinase $\mathrm{C}$ ( $\mathrm{PKC})$.
Penelitian lain juga membuktikan bahwa pemberian ekstrak etanol umbi bawang dayak (Eleutherine palmifolia (L.) Merr) dengan dosis $1 \mathrm{mg} / 20 \mathrm{gBB}$ dapat meningkatkan aktivitas apoptosis sel kanker kolon melalui ekspresi caspase3 dan TNF- $\alpha$ (Firsyaradha, 2019). Menurut hasil penelitian Wijayanti dan Noor (2018), secara in vivo pemberian ekstrak umbi bawang dayak dengan dosis $750 \mathrm{mg} / \mathrm{kgBB}$ selama 7 hari dapat memperbaiki inflamasi pada kolon. Ekstrak umbi bawang dayak mampu meningkatkan kadar MDA yang bersifat mutagenik dan meningkatan kadar SOD jaringan yang merupakan salah satu antioksidan enzim yang ada di dalam tubuh. Adanya efek antiinflamasi dari ekstrak umbi bawang dayak layak untuk dijadikan sebagai antikanker dengan dilakukan penelitian lebih lanjut secara ilmiah. Penelitian menurut Lestari dkk (2019), fraksi kloroform dari ekstrak etanol umbi bawang dayak dengan $\mathrm{LD}_{50} 187,068 \mathrm{mg} / \mathrm{KgBB}$ dapat memberikan efek toksik dengan ditandai adanya kematian pada mencit dengan pengamatan selama 24 jam . Beberapa studi pre-klinik dengan mekanisme kerja secara in vivo dirangkum pada tabel 3 .

Tabel 3 Rangkuman studi pre-klinik dan mekanisme kerja secara in vivo

\begin{tabular}{|c|c|c|c|c|c|}
\hline No. & Bahan & $\begin{array}{l}\text { Senyawa/ } \\
\text { Golongan } \\
\text { Senyawa }\end{array}$ & Aktivitas & Mekanisme Kerja & Pustaka \\
\hline 1. & $\begin{array}{l}\text { Ekstrak } \\
\text { etanol } 96 \% \\
\text { umbi bawang } \\
\text { dayak } \\
\text { (Eleutherine } \\
\text { palmifolia (L.) } \\
\text { Merr }\end{array}$ & $\begin{array}{l}\text { Oxyresveratrol } \\
\text { (Golongan } \\
\text { polifenol) }\end{array}$ & $\begin{array}{l}\text { Aktivitas sitotoksik } \\
\text { pada kanker kolon } \\
\text { dengan dosis } 0,50 \\
\mathrm{mg} / 20 \mathrm{gBB}\end{array}$ & 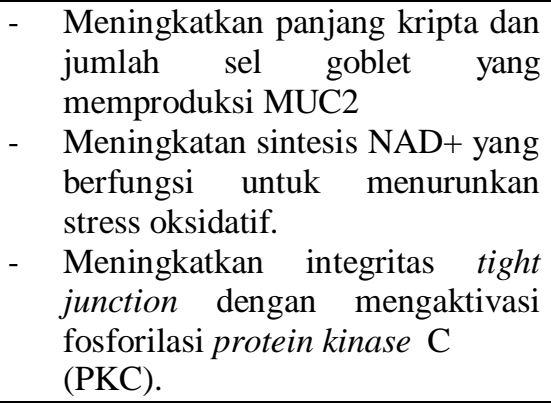 & Sari (2019) \\
\hline 2. & $\begin{array}{l}\text { Ekstrak } \\
\text { etanol } 96 \% \\
\text { umbi bawang } \\
\text { dayak } \\
\text { (Eleutherine } \\
\text { palmifolia (L.) } \\
\text { Merr) }\end{array}$ & $\begin{array}{l}\text { Golongan } \\
\text { flavonoid }\end{array}$ & $\begin{array}{l}\text { Aktivitas sitotoksik } \\
\text { terhadap sel kanker } \\
\text { kolon dengan dosis } \\
1 \mathrm{mg} / 20 \mathrm{gBB}\end{array}$ & $\begin{array}{l}\text { - Meningkatan aktivitas apoptosis } \\
\text { dengan adanya peningkatan } \\
\text { ekspresi caspase-3 dan TNF- } \alpha\end{array}$ & $\begin{array}{l}\text { Firsyaradha } \\
(2019)\end{array}$ \\
\hline 3. & $\begin{array}{l}\text { Ekstrak } \\
\text { etanol } 96 \% \\
\text { umbi bawang } \\
\text { dayak } \\
\text { (Eleutherine } \\
\text { palmifolia (L.) } \\
\text { Merr) }\end{array}$ & $\begin{array}{l}\text { - Golongan } \\
\text { polifenol } \\
\text { - Golongan } \\
\text { flavonoid }\end{array}$ & $\begin{array}{l}\text { Aktivitas } \\
\text { antiinflamasi pada } \\
\text { kolon dengan dosis } \\
750 \mathrm{mg} / \mathrm{kgBB}\end{array}$ & $\begin{array}{l}\text { - Meningkatkan kadar MDA yang } \\
\text { bersifat mutagenik } \\
\text { - Meningkatan kadar SOD jaringan } \\
\text { yang merupakan salah satu } \\
\text { antioksidan enzim yang ada di } \\
\text { dalam tubuh }\end{array}$ & $\begin{array}{l}\text { Wijayanti dan } \\
\text { Noor (2018) }\end{array}$ \\
\hline 4. & $\begin{array}{l}\text { Fraksi } \\
\text { kloroform } \\
\text { umbi bawang } \\
\text { dayak } \\
\text { (Eleutherine } \\
\text { palmifolia (L.) } \\
\text { Merr) }\end{array}$ & $\begin{array}{l}\text { - Golongan } \\
\text { flavonoid } \\
\text { - Golongan } \\
\text { naftokuinon }\end{array}$ & $\begin{array}{l}\text { Memberikan efek } \\
\text { toksik dengan nilai } \\
\mathrm{LD}_{50} \quad 187,068 \\
\mathrm{mg} / \mathrm{KgBB}\end{array}$ & $\begin{array}{l}\text { - Efek toksik dengan ditandai adanya } \\
\text { kematian pada mencit dengan } \\
\text { pengamatan selama } 24 \text { jam. }\end{array}$ & $\begin{array}{l}\text { Lestari } \\
(2019)\end{array}$ \\
\hline
\end{tabular}




\section{Studi Pre Klinik dan Mekanisme Kerja secara In Silico}

Berdasarkan studi pre-klinik secara in silico, menurut penelitian Amelia dkk (2015), senyawa eleutherinol dalam umbi bawang dayak juga dapat menghambat reseptor estrogen alpha $(\mathrm{ER} \alpha)$ kanker payudara dengan nilai ikatan energi sebesar $-6,43 \mathrm{kkal} / \mathrm{mol}$ terhadap reseptor 3ERT. 3ERT merupakan kode yang digunakan untuk pengunduhan reseptor estrogen alpha $(\mathrm{ER} \alpha)$. Senyawa eleutherinol memiliki dua ikatan hidrogen dengan GLU353 dan ARG394 asamamino yang dapat menghambat reseptor estrogen alpha (ER $\alpha)$. Penelitian Narko dkk (2017), juga membuktikan bahwa senyawa eleutherinoside A dalam umbi bawang dayak mampu menghambat pertumbuhan kanker serviks yang memiliki ikatan lebih kuat dibandingkan dengan 5 Fluorourasil sebagai senyawa obat pembanding. Senyawa eleutherinoside A memiliki nilai ikatan energi sebesar $-9,55$ $\mathrm{kkal} / \mathrm{mol}$ terhadap reseptor 5UU1 dan nilai ikatan energi sebesar -7,63 kkal/mol terhadap reseptor 3ERT, yang mana menunjukkan lebih baik dibandingkan 5 Fluorourasil sebagai obat pembanding. Struktur reseptor VHR diunduh dari situs PDB dengan kode 5UU1 sedangkan struktur reseptor ER $\alpha$ (Estrogen alfa) diunduh dengan kode 3ERT. Hasil penambatan senyawa Eleutherinoside A terhadap reseptor 5UU1 menunjukkan ikatan hidrogen dengan asam amino LYS61, LEU124, GLU122, ILE35, dan ASP127. Sedangkan untuk hasil penambatan senyawa Eleutherinoside A terhadap reseptor 3ERT menunjukkan ikatan hidrogen dengan asam amino GLU353, LEU346, dan THR347.
Penelitian Muti'ah dkk (2019), membuktikan bahwa senyawa isoliquiritigenin dan senyawa oxyresveratrol dalam umbi bawang dayak mampu menghambat pertumbuhan kanker yang memiliki ikatan lebih kuat dibandingkan dengan 2,3-dihydro-1,4-benzoxazine dan phenylacylsulfonamide sebagai senyawa obat pembanding. Senyawa isoliquiritigenin memiliki nilai ikatan energi sebesar - 68.0282 terhadap reseptor 2RL5 dan nilai ikatan energi sebesar - 78.5041 terhadap reseptor 4AQ3-E. Sedangkan senyawa oxyresveratrol memiliki nilai ikatan energi sebesar - 73.0413 terhadap reseptor 2RL5 dan nilai ikatan energi sebesar 87.9985 terhadap reseptor 4AQ3-E. Struktur reseptor VEGFR-2 diunduh dari situs PDB dengan kode 2RL5 sedangkan struktur reseptor BCL-2 diunduh dengan kode 4AQ3-E. Hasil penambatan senyawa isoliquiritigenin terhadap reseptor 2RL5 (reseptor VEGFR-2) menunjukkan ikatan hidrogen dengan asam amino THR916, CYS919, LYS868, dan VAL914. Sedangkan untuk hasil penambatan senyawa isoliquiritigenin terhadap reseptor 4AQ3-E (reseptor BCL-2) menunjukkan ikatan hidrogen dengan asam amino ARG66, ASP62, ARG105 dan TYR67. Selanjutnya hasil penambatan senyawa oxyresveratrol terhadap reseptor 2RL5 (reseptor VEGFR-2) menunjukkan ikatan hidrogen dengan asam amino GLU917, CYS919, LYS868, dan VAL914. Sedangkan untuk hasil penambatan senyawa oxyresveratrol terhadap reseptor 4AQ3-E (reseptor BCL-2) menunjukkan ikatan hidrogen dengan asam amino LEU160, ALA59, GLN58 dan TYR67. Beberapa studi pre-klinik dengan mekanisme kerja secara in silico dirangkum pada tabel 4.

Tabel 4. Rangkuman studi pre-klinik dan mekanisme kerja secara in silico

\begin{tabular}{|c|c|c|c|c|c|}
\hline No. & $\begin{array}{c}\text { Bahan/ } \\
\text { Ekstrak }\end{array}$ & $\begin{array}{l}\text { Senyawa/ } \\
\text { Golongan } \\
\text { Senyawa }\end{array}$ & Aktivitas & Mekanisme Kerja & Pustaka \\
\hline 1. & $\begin{array}{l}\text { Ekstrak umbi } \\
\text { bawang dayak } \\
\text { (Eleutherine } \\
\text { palmifolia } \\
\text { (L.) Merr) }\end{array}$ & Eleutherinol & 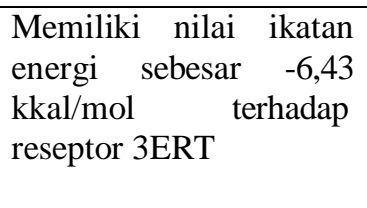 & $\begin{array}{l}\text { Asam amino GLU353 dan ARG394 } \\
\text { menghambat reseptor estrogen } \\
\text { alpha }(E R \alpha) \text { kanker payudara }\end{array}$ & $\begin{array}{l}\text { Amelia dkk } \\
(2015)\end{array}$ \\
\hline 2. & $\begin{array}{l}\text { Ekstrak umbi } \\
\text { bawang dayak } \\
\text { (Eleutherine } \\
\text { palmifolia (L.) } \\
\text { Merr) }\end{array}$ & $\begin{array}{l}\text { Eleutherinoside } \\
\text { A }\end{array}$ & 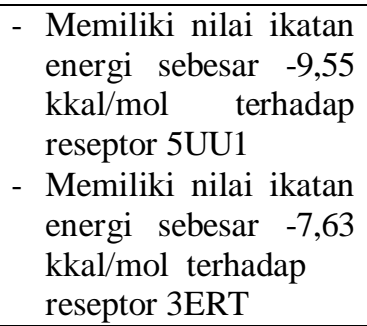 & 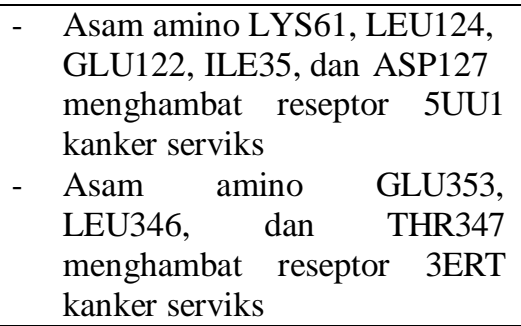 & $\begin{array}{l}\text { Narko dkk } \\
\text { (2017) }\end{array}$ \\
\hline 3. & $\begin{array}{l}\text { Ekstrak umbi } \\
\text { bawang dayak } \\
\text { (Eleutherine } \\
\text { palmifolia (L.) } \\
\text { Merr) }\end{array}$ & $\begin{array}{l}\text { - Isoliquiritigenin } \\
\text { - Oxyresveratrol }\end{array}$ & 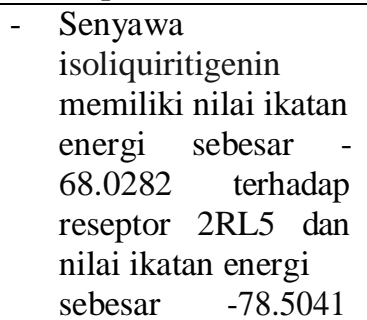 & 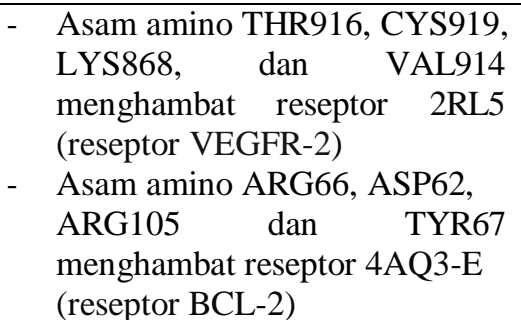 & $\begin{array}{l}\text { Muti'ah dkk } \\
\text { (2019) }\end{array}$ \\
\hline
\end{tabular}




\begin{tabular}{|c|c|}
\hline terhadap & - $\quad$ Asam amino GLU917, CYS919, \\
\hline 4AQ3-E. & LYS868, \\
\hline Senyawa & menghambat reseptor \\
\hline oxyresveratrol & (reseptor VEGFR-2) \\
\hline memiliki nilai ikatan & - Asam amino LEU160, ALA59, \\
\hline sebesar & GLN58 \\
\hline $\begin{array}{l}73.0413 \text { terhadap } \\
\text { reseptor 2RL5 dan } \\
\text { nilai ikatan energi } \\
\text { sebesar }-87.9985\end{array}$ & $\begin{array}{l}\text { menghambat reseptor } 4 \mathrm{AQ} 3-\mathrm{E} \\
\text { (reseptor BCL-2). }\end{array}$ \\
\hline $\begin{array}{ll}\text { terhadap } & \text { reseptor } \\
\text { 4AQ3-E. } & \end{array}$ & \\
\hline
\end{tabular}

\section{Kesimpulan}

Secara empiris umbi bawang dayak (Eleutherine palmifolia (L.) Merr) dapat digunakan untuk pengobatan kanker payudara, kanker usus, hipertensi, diabetes melitus, stroke, demam, disuria, radang usus, disentri, penyakit kuning, obat bisul, kista, prostat, penurun kolesterol serta trigliserida, pelancar ASI dan gangguan seksual. Dalam pengobatan kanker, umbi bawang dayak (Eleutherine palmifolia (L.) Merr) digunakan dengan cara mengeringkan umbi dan mengunyahnya.

Aktivitas senyawa golongan flavonoid, golongan polifenol dan golongan naftokuinon serta turunannya dalam ekstrak umbi bawang dayak (Eleutherine palmifolia (L.) Merr.) telah terbukti secara ilmiah dapat digunakan sebagai obat antikanker. Studi pre-klinik dengan mekanisme kerja secara in vitro dan in vivo menunjukkan bahwa ekstrak umbi bawang dayak (Eleutherine palmifolia (L.) Merr) mampu menghambat signaling sel melalui pemacuan apoptosis dan cell cycle arrest. Selain itu, mekanisme kerja secara in silico memiliki aktivitas antikanker dari penghambatan reseptor VHR, BCL-2, VEGFR-2 dan reseptor estrogen alpha (ER $\alpha)$.

\section{Daftar Pustaka}

[1] Ahmad, I., Neneng, S. S. A., Niken, I., Yurika, S., Laode, R., Abdul, M. 2018. Oral Glucose Tolerance Activity of Bawang Dayak (Eleutherine palmifolia L. Merr.) Bulbs Extract Based on the Use of different Extraction Method. Pharmacognosy Journal. Volume 10, Issue 1: 49-54.

[2] Amelia, T., Dina, P., Romsiah, Daryono, H. T. 2015. In Silico Study of The Component of Eleutherine americana MERR. on Human Estrogen Reseptor Alpha as Potential Anti-Breast Cancer. International Conference on Computation for Science and Technology.

[3] Chen, D. L., Mei, G. H., Yang-Yang, L., Rong, T. L., Meng, Y., Xu-Dong, dkk. 2018. New Naphthalene Derivatives from the Bulbs of Eleutherine americana with Their Protective Effect on the Injury of HUVECs. Molecules. Volume 23.

[4] Firsyaradha, W. Y. 2019. Pengaruh Pemberian Tablet Bawang Dayak (Eleutherine palmifolia (L.) Merr) terhadap Apoptosis Sel Kanker Kolon pada Model Hewan Coba yang Diinduksi AOM DSS. Skripsi Belum Diterbitkan. Malang: Program Studi Farmasi Universitas Islam Negeri Maulana Malik Ibrahim

[5] Fitri, Y., Rosidah, E. S. 2014. Effects of Inhibition Cell Cycle and Apoptosis of Sabrang Onion Extract (Eleutherine bulbosa (Mill.) Urb.) on Breast Cancer Cells. International Journal of PharmTech Research. Volume 6, Nomor 4.
[6] Ha, L. M., Do, T. T. H., Phan, V. K., Chau, V. M., Nguyen, T. H. V., Nguyen, X. N., dkk. 2013. Chemical Constituents of the Rhizome of Eleutherine bulbosa and Their Inhibitory Effect on the Pro-Inflammatory Cytokines Production in Lipopolysaccharide-Stimulated Bone Marrow-derived Dendritic Cells. Bull. Korean Chem. Soc. Volume 34, Issue 2.

[7] Hidayah, A. S., Kiki, M., Leni., P. 2015. Uji Aktivitas Antioksidan Umbi Bawang Dayak (Eleutherine bulbosa Merr.). Prosiding Penelitian SPeSIA Unisba.

[8] Insanu, M., Siti, K., Rika, H. 2014. Recent Studies on Phytochemicals and Pharmacological Effects of Eleutherine americana Merr.Procedia Chemistry. Volume 13: 221 - 228.

[9] Kemenkes RI. 2018. Profil Kesehatan Indonesia 2018. Jakarta: Keputusan Menteri kesehatan Republik Indonesia.

[10] Kopustinskiene, D. M., Valdas, J., Arunas, S. snd Jurga, B. 2020. Flavonoids as Anticancer Agents. Nutrients. Volume 12.

[11] Lestari, D., Rudi, K., Eva, M. 2019. Antioxidant and Anticancer Activity of Eleutherine bulbosa (Mill.) Urb on Leukemia Cells L1210. Journal of Physics: Conference Series. Issue 1277.

[12] Lestari, D., Rudi, K., Eva, M. 2019. Uji Brine Shrimp Lethality Test (BSLT) Umbi Bawang Tiwai (Eleutherine bulbosa (Mill.) Urb) dan Uji Toksisitas Akut Fraksi Aktif. Jurnal Riset Kefarmasian Indonesia. Volume 1, Nomor 1.

[13] Li, X., Ohtsuki, T., Koyano, T., Kowithayakorn, T., Ishibashi, M. 2009. New Wnt/ $\beta$-Catenin Signaling Inhibitors Isolated from Eleutherine palmifolia. Chemistry An Asian Journal. Volume 4: 540-547.

[14] Mahabusarakam, W., Hemtasin, C., Chakthong, S., Voravuthikunchai, S.P., Olawumi, I.B. 2010. Naphthoquinones, Anthraquinones and Naphthalene Derivatives from The Bulbs of Eleutherine americana. Planta Med. Volume 76.

[15] Mardiyaningsih, Ana and Ismiyati, Nur. 2014. Aktivitas Sitotoksik Ekstrak Etanolik Daun Alpukat (Persea americana Mill.) pada Sel Kanker Leher Rahim HeLa. Traditional Medicine Journal. Volume 19, Nomor 1.

[16] Minggarwati, T.S. 2017. Uji Aktivitas Antikanker dan Identifikasi Senyawa Aktif dari Fraksi Umbi Bawang Sabrang (Eleutherine palmifolia (L.) Merr.) terhadap Sel Kanker Serviks Hela. Skripsi. Malang: Universitas Islam Negeri Maulana Malik Ibrahim Malang.

[17] Muti'ah, R., Anik, L., Arief, S., Rahmi, A., Abdul, H., Wirda, A., dkk. 2018. Activity of Inhibit The Cell Cycle and Induct 
Apoptosis in HeLa Cancer Cell with Combination of Sabrang onion (Eleutherine palmifolia (L.) Merr) and Starfruit Mistletoe (Macrosolen cochinchinensis (Lour.) Tiegh). Journal of Applied Pharmaceutical Science. Volume 8, Nomor 10: 122-128.

[18] Muti'ah, R., Chorida, M. H. Burhan, M. Z. A,Weka, S. B. Rahmi, A., Yen Yan A. I, dkk. 2019. Metabolite Fingerprinting of Eleutherine palmifolia (L.) Merr. By HPTLC-Densitometry and Its Correlation with Anticancer Activities and In Vitro Toxicity. Indonesian Journal of Pharmacy. Volume 30, Nomor 3: $157-166$.

[19] Muti'ah, R., Trian, S. M., Risma, A. K., Erna, S. 2019. Compound Identification and Anticancer Activity of Ethyl Acetate Fraction from Bawang Sabrang (Eleutherine palmifolia (L.) Merr.) on HeLa Cervical Cancer Cell Line. Indonesian Journal of Cancer Chemoprevention. Volume10, Nomor 3.

[20] Narko, T., Benny, P., Riska, P., Dang, S., Faridhatul, K. 2017. Molecular Docking Studyof Bulb Of Bawang Dayak (Eleutherine palmifolia (L) Merr) Compound as Anti Servical Cancer. Jurnal Ilmiah Farmako Bahari. Volume 8, Issue 2: 1-14.

[21] Nascimento, M. S., Vieira, J. M. S., Malheiros, L. C. S ., Silva, J. O. C., Rodrigues, L. C. S. And Barbosa, W. L. R. 2012. Characterisation Of Isoeleutherine In Aqueous Extract Of Eleutherine Plicata Herb, Iridaceae, Active Against Entamoeba Hystolitica/ Entamoeba Dispar In-Vitro. International Journal of Pharmaceutical Sciences and Research. Volume 3, Isssue 4: 1096-1100.

[22] Naspiah, N., Yoppi, I., Moelyono, M. W. 2014. Artikel Ulasan: Bawang Tiwai (Eleutherine americana Merr.), Tanaman Multiguna. Indonesian Journal of Applied Sciences (IJAS). Volume 4, Nomor 2.

[23] Pereyra, C. E., Rafael, F. D., Sabrina, B. F., Luciano, P. G., Floriano, P. S. 2019. The Diverse Mechanisms and Anticancer Potential of Naphthoquinones. Cancer Cell International. Volume 19, Issue 207.

[24] Poerwosusanta, H., Mulyohadi, A., Zairin, N., Karyono, M., Edi, W. 2018. Potensi Ekstrak Bawang Dayak (Eleutherine Sp) sebagai Obat Herbal Terstandar (OHT) pada Pengobatan Medis. Jurnal Ilmiah Ibnu Sina. Volume 3, Nomor 2: 242-251.

[25] Pratama, M., R., F. and Isna, R., A. 2019. Molecular Docking of Bawang Dayak (Eleutherine bulbosa) Secondary Metabolites as Bacterial Cell Wall Synthesis Inhibitor. 1st International Conference on Science and Technology.

[26] Prayitno, B., Bayu, H. M., Lagiono. 2018. Optimasi Potensi Bawang Dayak (Eleutherine sp.) sebagai Bahan Obat Alternatif. Jurnal Pendidikan Hayati. Volume 4, Nomor 3: 149-158.

[27] Puspadewi, R., Putranti, A., Rizka, M. 2013. Khasiat Umbi Bawang Dayak (Eleutherine palmifolia (L.) Merr.) sebagai
Herbal Antimikroba Kulit. Kartika Jurnal Ilmiah Farmasi. Volume 1, Nomor 1: 31-37.

[28] Putri, Erika Nuur Anisa dan Haryoto. 2018. Aktivitas Antikanker Ekstrak Etanol Umbi Bawang Dayak (Eleutherine americana Merr.) Terhadap Sel Kanker Payudara T47D. University Research Colloqium.

[29] Sari, R. A. 2019. Pengaruh Pemberian Tablet Bawang Dayak (Eleutherine palmifolia (L.) Merr.) terhadap Histopatologi Kolon dan Tingkat Toksisitas Hepar Model Hewan Coba Kanker Kolon yang Diinduksi AOM/DSS. Skripsi Belum Diterbitkan. Malang: Program Studi Farmasi Universitas Islam Negeri Maulana Malik Ibrahim.

[30] Sudarmawan, I. H., Djoko, D., Ambar, M., Dyah, R. B. 2010. Pengaruh Pemberian Fraksi Etanolik dan Petroleum Eter Ekstrak Umbi Bawang Dayak (Eleutherine palmifolia) terhadap Ekspresi p53 Mutan pada Galur Sel Kanker Payudara T47D. Biofarmasi. Volume 8, Nomor 1: 17-26.

[31] Sun, Y., Zhao Zhao, Zhang-Nv, Y., Fang, X., Hang-Jing, L., dkk. 2017. Risk Factors and Preventions of Breast Cancer. International Journal Biological Sciences. Volume 13, Nomor 11: 1387-1397.

[32] Wang, Z, Wang, N., Han, S., Wang, D., Mo, S., Yu, L. 2013. Dietary compound isoliquiritigenin inhibits breast cancer neoangiogenesis via VEGF/VEGFR-2 signaling pathway. PLoS One. Volume 8.

[33] Wigati, D. dan Ryan, R. R. 2018. Penetapan Standarisasi Non Spesifik Ekstrak Etanol Hasil Perkolasi Umbi Bawang Dayak (Eleutherine palmifolia (L.)Merr). Jurnal Ilmu Farmasi dan Farmasi Klinik (JIFFK). Volume 15, Nomor 2: 36-40.

[34] Wijayanti, Sudarma Dita dan Noor, Hasyati. 2018. Potensi Ekstrak Umbi Bawang Dayak (Eleutherine palmifolia (L.) Merr.) dalam Mencegah Ulcerative Colitis pada Mencit yang Diinduksi DSS (Dextran Sulphate Sodium). Jurnal Ilmu Pangan dan Hasil Pertanian. Volume 2, Nomor 1.

[35] Yang, J., Wen, C., Pan, C., Guo, H., Zhao, W., Zhang, J, dkk. 2019. Nanoliposomal Multi-Drug Delivery System With Reduced Toxicity And Multi-Drug Resistance. Journal of Materials Science, 54(13), 9718-9728

[36] Yusni, Mohammad Ali. 2008. Perbedaan Pengaruh Pemberian Fraksi Etanolik Bawang Dayak (Eleutherine palmifolia L. Merr) dengan 5-Fluorouracil terhadap Penghambatan Pertumbuhan Galur Sel Karsinoma Kolon HT29 dan Ekspresi P53 Mutan. Skripsi. Fakultas Kedokteran, Universitas Sebelas Maret Surakarta.

[37] Zuhud, E. A. M. 2011. Bukti Kedahsyatan Sirsak Menumpas Kanker. Jakarta : PT. Agromedia. 